ractive plants with bright pink to white, rather fragrant, flowers which are conspicuous in the spring in sandy places, especially in Arizona and California.

Abronia micrantha is an annual, up to ft. high, with succulent, pale stems that are enlarged at the nodes. The paired leaves are petiolate, entire, lanceolate to ovate, farinose below, and have prominent veins. Sheathing stipules (ochrea) are absent but are present in the similar Sand Dock.

The tiny flowers are quite showy as they are arranged in dense "heads" with a ring of bracts underneath. The flowers themselves are very interesting as they lack petals but have a petalloid calyx in the form of a long tube which ends in 5 petal-like lobes (Fig. 3 ). The stamens lie inside this tube while the ovary is found at its base. A curious thing happens when the ovary becomes a fruit. The base of the calyx tube becomes transformed into a winged structure, closely enclosing the fruit and aiding in its dispersal. These winged fruits are characteristic and look quite attractive as they are pale green with a pink blush. (Fig. 2).

This species is of interest as it is usually associated with desert or semidesert conditions. Sand Verbenas are "ephemerals", i.e., they cover the desert in the spring with a blaze of colour, then set seed and die. This is an adaptation to desert conditions, and a very successful one, as the plants survive the torrid heat of midsummer as dormant seeds. Abronia micrantha has been found growing on sand dunes and dry ground in the Mohave Desert, California, Arizona, Nevada, Colorado and Montana.

\title{
SOME BUTTERFLIES AND BIRDS AT HASBALA LAKE, SASKATCHEWAN
}

\author{
by RONALD R. HOOPER*
}

Hasbala Lake is Saskatchewan's northeasternmost lake. It sits astride the Saskatchewan-Manitoba border, and the north shore comes within $1 / 2$ mile of the Northwest Territories. It is in the sub-arctic zone and is only about 75 miles from the barren grounds. On June 27, 1973, I began a 7-day field trip there for the Provincial Museum accompanied by a

* Bux 20)5,

Fort Qu Appelle, Silsk.

S()G IS() botanist, Bernard DeVries. We flew from La Ronge, stopping at Kinosao on Reindeer Lake to refuel enroute. We set up camp on a knoll near the southwest corner of the lake.

Much of the area on the west and south shores of the lake had been burned by a forest fire a few years previously. Outsicie of this burned area the predominant trees were black spruce. There were also sand blowout areas with jack pines. Birch grew along the eskers. Poplars and white spruce were scarce. The forest cover was, in 
most places, not dense with either trees or shrubs, and in some areas it was relatively open country - the tops of the eskers, the steeper hollows or kettles between the eskers, boulder areas along or near streams, and the sand blowouts. Outcrops of bedrock were rare.

The weather was hot and extremely dry. The lichens crunched like corn flakes under our feet. The blackflies were plentiful and ferocious in the daytime, and there were enough mosquitoes at night to keep things lively.

I did not find a great variety of insects, but some were of interest. Among the beetles collected were the Tiger Beetle (Cicindela limbata hyperborea Leconte) in the sand blowouts, and the Predaceous Diving Beetle (Agabus tristis Aube) in a creek. Some interesting moths were taken. The noctuid Sympistis melaleuca (Thun.) was plentiful on the top of eskers. The geometrid Aspilates taylorae (But.) was also taken. It resembles our prairic Aspilates orciferaria Wlk., but it lacks the median dark spot on the underside of the hindwing.

\section{BUTTERFLIES}

The following is an account of the 12 species of butterflies recorded:

GRIZZLED SKIPPER (Pyrgus centaureae freija Warren) - six specimens collected on July 3 , and two on July 4 , all in somewhat worn condition. They were found on wet moss along the edge of open bogs. It was the first time I had collected the species although it had previously been found at Wachee in the Pasquia Hills by John Masters.

PALAENO SULPHUR (Colias palaeno chippewa Edwards) - 16 specimens wcre collected in open forest areas. More than 50 percent of the females were albinistic. I have previously collected it in Saskatchewan only at Stony Rapids; Gary Anweiler collected one at Black Lake.

DORCAS COPPER (Lycaena dorcas Kirby) - this species was not seen on the wing when we first arrived but two freshly emerged males were taken on July 3 open bogs.

YUKON BLUE (Plebejus optilete yukond Holland) - fairly common along the top of eskers where there was an abundance of the Dry Ground Cranberry (Vaccinilum viti idaea L.) on which the caterpillars probably feed.

ARCTIC BLUE (Plehejus aquilo Boisduval - found among boulders along a strean and along the north slope of one of the bigger kettles. The specimens seem to by lighter underneath than $P$. aquilo lacustri. Frceman and tend toward the arctic sub species $P$. a. aquilo.

PAINTED LADY (Vanessa cardui Linnaeus - a few tattered specimens were seen along the eskers and one was collected. It is interesting that this species, which migrated into southern Saskatchewan in large num. bers in 1973, reached this far north.

SILVER BORDERED FRITILLARY (Boloric selene Schiffermueller) - found locally in grassy areas along the shores of lakes.

FRIGGA FRITILLARY (Boloria firigga sagc Staudinger) - uncommonly seen. Sever specimens collected on Junc 27 and 28.

FREIJA FRITILLARY (Boloria freija Thunberg) - occasionally seen and collected The specimens werc quitc worn, indicating that they had been on the wing for some time.

PURPLE LESSER FRITILLARY (Boloric titania boisduvali Duponchel) - this was the commonest butterfly. Fifty-three specimen wcre taken. It was the first time that this subspecies has been taken in the province Alexander Klots was kind enough to check the identification for me. This subspecies has been previously taken south to Chur. chill, Manitoba, and Fort Rae, Northwes Territories. At Hasbala Lake it was found scattered throughout the wooded areas. If was surprising to find it so early in the sum. mer, because Boloria titania grandis Barnes and McDunnough of farther south does not emerge until mid-July. Perhaps it emergen early because of the hot, dry wcather. It dif. fers from $B$. $t$. grandis in the following points: (a) it averages a little smaller $(30$ $36 \mathrm{~mm}$ wing spread); (b) the wings have a more extensive dark basal area on the up. per side; (c) the darker areas on the under. side of the hindwings are a lighter shade of brown: (d) the white and tawny areas on the underside of the hindwings are a little more clearly defined, and sometimes more extensive; and (e) on B. $t$. grandis the broad median band on the underside of the hindwing is undivided. On $B$. $t$. boriscluvali this broad band is divided by an "X" on $1 / 4$ of our specimens. 


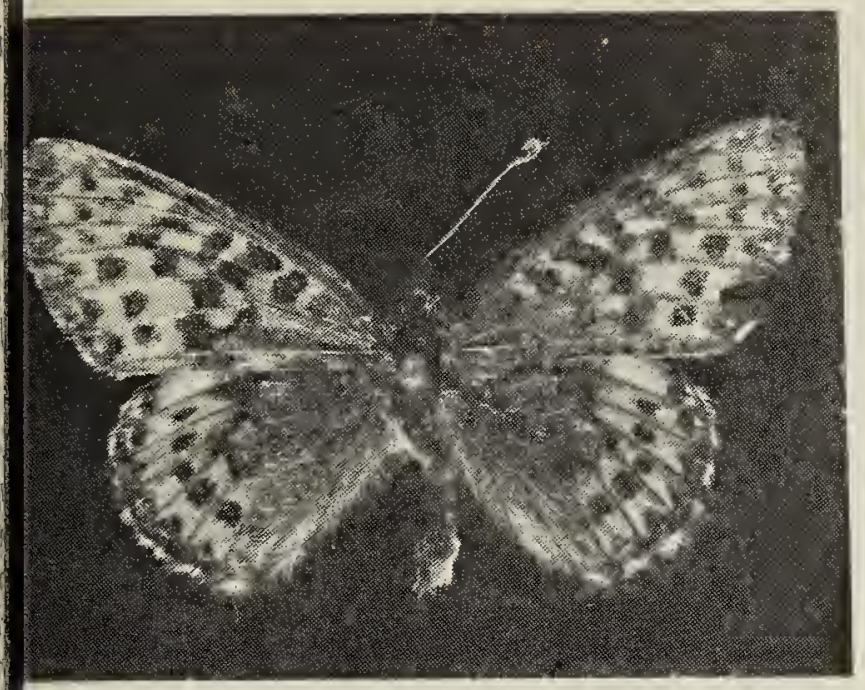

urple Lesser Fritillary.

lale, upperside.

OG FRITILLARY (Boloria eunomia Esper) three specimens collected on June 27.

JTTA ARCTIC (Oeneis jutta Huebner) ree specimens collected and a few others en in some of the thicker stands of black ruce.

\section{BIRDS}

Although no time was taken to search for rds, I recorded those that we heard or w. Those not listed in The birds of prtheastern Saskatchewan are marked with asterisk.'

OMMON LOON. Seen twice. One pair frthwest of camp on a small lake on June 9: one calling on Hasbala Lake, June 30. ED-NECKED GREBE. One on a pond prthwest of camp on June 29. GULLS. nidentified white-headed gulls were seen ery day. COMMON GOLDENEYE. One lick seen on June 30 at a distance may live been this species. One pair was sitively identified on July 2. We saw surisingly few ducks. SCAUP. A pair on a ind about 4 miles south of Hasbala Lake peared to be so large that they must have en Greater Scaup. I did not see them in ight. GOSHAWK. One south of camp on hy 2. SPRUCE GROUSE. One on June , south of camp. WILLOW PTARMIGAN. eathers found on June 29. COMMON NIPE. One winnowing over camp in the enings. SPOTTED SANDPIPER. One was en on June 30. SOLITARY SANDPIPER. ne in marsh northwest of camp on June 9. LESSER YELLOWLEGS. Two pair folding us on June 29. SHORT-EARED WL. One on June 28 near our camp. OMMON

(YELLOW-SHAFTED) LICKER. One northeast of camp on June 9. YELLOW-BELLIED FLYCATCHER. alling near camp, June 28 and 29.

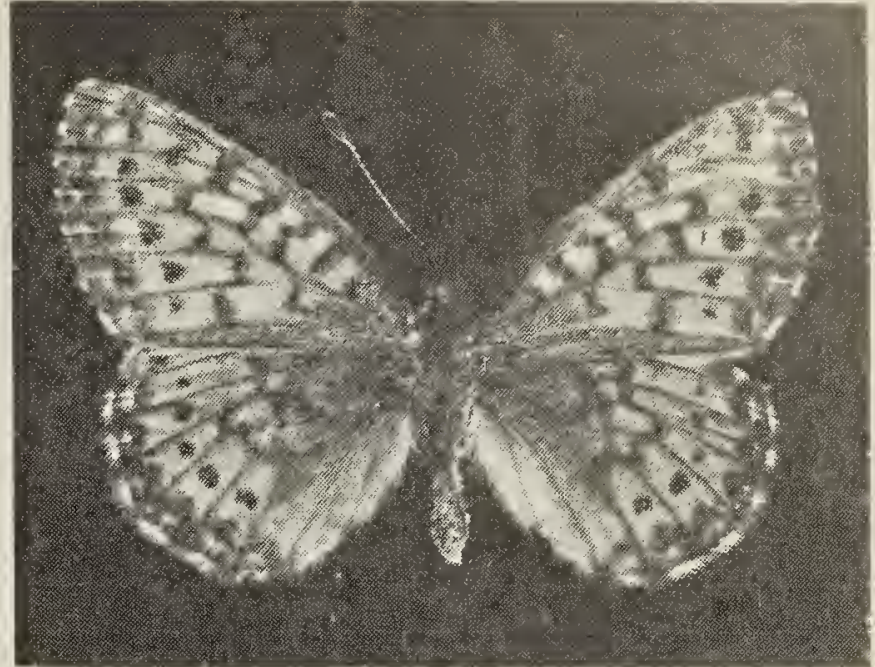

Female, upperside

OLIVE-SIDED FLYCATCHER. One near our camp on July 2. TREE SWALLOW. Two near camp on July 2. GRAY JAY. One south of camp on June 28. COMMON RAVEN. One on June 30. BOREAL CHICKADEE. A flock on June 30. AMERICAN ROBIN. One on June 30. HERMIT THRUSH. One heard singing in evening south of camp on June 27. *VEERY. One heard on June 30. YELLOWRUMPED (MYRTLE) WARBLER. Two pair on July 2. BOHEMIAN WAXWING. One flew over camp on July 2. ${ }^{*}$ WINTER WREN. A wren seen near our camp on June 30 was probably this species. The song was a little like that of a House Wren but longer and more musical. *BROWN THRASHER. One seen and heard singing near camp on July 2. RUSTY BLACKBIRD. One seen northwest of camp on June 29. PINE GROSBEAK. One scolding female south of camp, June 28. REDPOLL. Two flocks flew over camp on July 2. They were flying too high to distinguish the species. DARKEYED (SLATE-COLORED) JUNCO. One bob-tailed young seen, June 27; I adult on June 28. TREE SPARROW. One heard singing on June 27 and 28. HARRIS' SPARROW. Two seen June 28 perching on dry trees and stumps on the burn. WHITECROWNED SPARROW. Saw one pair and their nest of well feathered young south of camp on July 2. WHITE-THROATED SPARROW. Heard on July 2. FOX SPARROW. One seen on June 30. SONG SPARROW. One seen and heard on July 2. July 2.

INERO, R. W. 1967. The birds of northeastem Saskarchenkm. Spec. Pub. 6, Saskatchewaln Nat. Hist. Soc. Regina. 96 p. 